\title{
Refugees are Never Burdens on Host Community: The Case of Bhutanese Refugees in South Australia
}

\author{
Hirotaka Fujibayashi ${ }^{1}$ \\ ${ }^{1}$ Department of International Studies, Graduate School of Frontier Sciences, The University of Tokyo \\ 5-1-5 Kashiwano-ha, Kashiwa, Chiba 277-8563, Japan. \\ Email: h.fujibayashi13 [AT] gmail.com
}

\begin{abstract}
The study attempts to pose a question to the notion firmly rooted in the policy of governments that 'refugees are burdens' on the host communities, and then argue the potentials of refugees to become assets for the host communities by scrutinizing the case of Bhutanese refugees in South Australia. First, the study reviews the life of Bhutanese refugees in the refugee camps and the destination of their resettlement (South Australia), with specific focus on the socio-economic features. Second, the study moves on to the socio-economic impacts of Bhutanese refugees on host communities in South Australia. Results from the field researches conducted in refugee camps in Nepal and in the resettlement places in South Australia as well as intensive literature surveys clarified that Bhutanese refugees have fewer obstacles to integrate into the host communities than other conflict-related refugees residing in poor countries. Economic, social and cultural environment in South Australia has positive influences on the successful integration of Bhutanese refugees into the host communities. Lastly, the study discusses the benefits refugees would give on the host communities, and concludes refugees are never burdens on the host communities because they can potentially give benefits on the host communities under several conditions.
\end{abstract}

Keywords - Bhutanese refugee, Nepal, third country resettlement, South Australia

\section{INTRODUCTION}

The recent refugee crisis is severely straining protection capacity of destination countries. Responding to refugees represents a challenge to the current global order and justice and to the international cooperation because the causes of refugee movements are underpinned by conflicts, state failure and inequality of international political economy. The consequences have been related to security and spread of conflict, terrorism and transnationalism (Betts \& Loescher 2011). The contemporary refugee regime, whose legal basis is 1951 Convention Relating to the Status of Refugees (Refugee Convention) and 1967 Protocol Relating to the Status of Refugees (Refugee Protocol) (Betts 2009; Betts 2011; Newman 2003), is mainly composed of two norms: "asylum" and "burden-sharing" (Betts 2011). While "asylum" is considered to relate to the provision of protection to refugees who reach the territory of that state, "burden-sharing" is considered to be the provision of protection of refugees who are on the territory of another state through resettlement or financial contributions (Betts 2011).

Basically, the contemporary regime is premised on the understanding not just that states have the primary responsibility for the protection of refugees (Betts, Loescher \& Milner 2012), but that states have the ultimate rights to decide what to extent they commits to refugee protection. In the case of Australia, for instance, it is untrue that the country accepts all refugees referred to or recommended by the Office of the United Nations High Commissioner for Refugees (UNHCR), because the ultimate decision to grant a visa rests with Australia's Immigration Department (Karlsen 2016). As such, refugee problems cannot be solved forever, in the absence of states' willingness to provide refugees freedom of movement and rights to work. Increasing concerns about extremist movement or terrorism make states more and more reluctant to commit to refugee protection, and most states are implementing increasingly restrictive border control or asylum and immigration policies because securing their territories and citizens is fundamental and the most significant mandate for states. States are faced with a dilemma of weighing up its moral duty and humanitarian obligations against the self-interested desire to minimize the number of refuges on their territories (Suhrke 1998). Although UNHCR has sought for providing a durable solution (voluntary repatriation, local integration or third country resettlement) with refugees, a number of refugees have frequently remained in the protracted instability.

Contrary to the implicit that international society failed to meet the protection needs of refugees, there is a case that the third country resettlement has successfully progressed, which is the case of Bhutanese refugees. Bhutanese refugees are originally ethnic Nepalese resided in the southern part of Bhutan, but escaped from ethnic cleansing policy by the 
kingdom in around 1990. Most of Bhutanese refugees had lived in refugee camps in the Eastern Nepal nearly for 20 years, and then resettled in another country through the third country resettlement program. Although the refugee camps in Nepal had utmost over 100,000 refugees, the population decreased to less than 18,000 (UNHCR 2015). Hence, the Office of the United Nations High Commissioner for Refugees (UNHCR) and International Organization for Migration (IOM), two leading international refugee agencies, have announced that the case of Bhutanese refugees is the largest and most successful resettlement program (IOM 2015; Preiss 2016; UNHCR 2015).

Australia is a leading country of accepting Bhutanese refugees from miserable camps in Nepal, in alliance with the United States and Canada. It is almost impossible to paint a rosy picture for everyone, and thus so many cases of antagonism between new comers and long residing people are reported. But also, a high rate of suicide and mental illness among Bhutanese resettlers has actually been a social matter in the United States, while the case of resettlement of Bhutanese refugees in Australia has not cause big problems either for refugees or for residents in host community (Personal interview with a UNHCR officer at the UNHCR office in Damak, March 10, 2016). Refugees enjoy their new lives and willingly work for the host community on the one hand, and local residents welcome refugees and try to create a good relation with them on the other hand. In Australia, why have Bhutanese refugees successfully integrated into host community? What has enabled such a desirable situation? Answers towards those questions would have good implications for our understanding about the impacts of refugees and forced migration on host community, and would be help in overturning the firmly rooted notion that 'refugees are burdens.'

\section{OBJECTIVES AND METHODS}

The main objective of this study is questioning and considering again the firmly rooted notion in literature related to refugees and forced migration that 'refugees are burdens' on host community, and discussing possibilities of refugees to become an 'assets,' not a 'burden' on host community through exploration into the resettlement of Bhutanese refugees in South Australia. While the case of Bhutanese refugee resettlement is considered successful, little works has addressed the case, especially in Australia, yet. This study attempts to provide a new, in a way, perspective that 'refugees are never burdens on host community' as well as to argue the necessary conditions to determine the successful refugee integration into host community because refugees would potentially be able to give more benefits than costs on host community under several conditions.

This study is dependent on the results of literature surveys, but I also conducted field researches in refugee camps and resettlement places respectively to explore the circumstances of Bhutanese refugee communities. I went on a research trip to Eastern Nepal in March 2016 and to South Australia in August 2016. In Nepal, I visited the refugee camp of Bhutanese refugees. Besides observation, I had interviews with the UNHCR's officers and NGO workers working for Bhutanese refugees there. In Australia, I visited the Bhutanese refugee community at Salisbury in South Australia. I interviewed the Bhutanese community leader and residents as well as NGO workers in South Australia. In several parts of the interviews in South Australia, I applied the focus group interviewing method.

To find out the practice of supports for refugees, I also had several interviews with people working on refugee and forced migration issues in Tokyo and Geneva. Informants of this study include people working for the organizations relevant to refugee or (forced) migration issues such as UNHCR, International Organization for Migration (IOM), International Federation of Red Cross and Red Crescent Societies (IFRC) or International Committee of the Red Cross (ICRC).

\section{RESULTS}

\subsection{The Story of Bhutanese Refugees}

\subsubsection{Emergence of Refugees from the "World's Happiest Country"}

Druk Yul (the land of the Thunder Dragon, Bhutan) is a Royal Kingdom located in Eastern Himalaya, bordering China to north and India to south, east and west. Nepal is separated from Bhutan by the Indian State of Sikkim, which was an independent kingdom till 1975, but Nepali-speaking community historically spread from Nepal to the southern part of Bhutan (Hutt 1996; Hutt 1997). While the first migration of Nepali-speaking people to Bhutan traced back to 1624 (Mayilvagnan 2005), mass movement began after the Anglo-Bhutanese war in 1865 (Hutt 2005) and over 60,000 Nepalese were brought as labor forces by the royal family to make up the labor shortage in 19th century (Mayilvagnan 2005). In Bhutan, there was no written Constitution until recently, but all ethnic Nepalese (called Lhotsampa: "People of the South") earned full citizenship in the 1958 Nationality Law of Bhutan, which prescribed for granting equal and full Bhutanese citizenship to all those settled in the kingdom prior to 1958 (Hutt 1996; MoHA 1958). The existence of Lhotsampa was indispensable for the kingdom at that time because tax revenues from them was the kingdom's main source of cash income (Hutt 2005), but their existence gradually turned into a threat to the royal government as the numbers and influences of them increased (Hutt 2005; Mayilvagnan 2005).

New regulations on citizenship in 1977 and 1985 as well as the Marriage Act in 1980 narrowed the terms on who could acquire the citizenship and began to threaten the life of Lhotsampa (MoHA 1980; MoHA 1985; MoHA 1993). 
Moreover the 1988 census, which is said to be conducted only in Southern Bhutan, classified ethnic Nepalese into the following 7 categories: F1: Genuine Bhutanese; F2: Returned emigrants (those who had left Bhutan but returned); F3: Drop-outs (those not available during the time of Census); F4: A non-national woman married to a Bhutanese man; F5: A non-national man married to a Bhutanese woman; F6: Non-National (illegal settlers); F7: Non-National (illegal settlers) (Personal interview with Bhutanese refugees in South Australia, August 8, 2016; AHURA Bhutan 1994; Hutt 1996; Piper 1995).

After this census, it became difficult for Lhotsampa (most of whom were categorized in other than F1) to remain in Bhutan because they were more or less identified as illegal immigrants (CoA 2007; RGB 1991). That is, people who were granted Bhutanese citizenship under the 1958 Citizenship Act lost their citizenship in 1988. Since the adaptation of the "One People, One Nation" policy in 1989, government of Bhutan has imposed the entire populace of Bhutan on cultural codes such as the use of Dzongkha language, observance of religion and wearing of traditional dress of Drukpa (Gho for men and Kira for women) to promote a distinct national identity through a revival of Drukpa tradition (Mayilvagnan 2005), and protests against these policies by Lhotsampa were recognized as "anti-national" or terrorism activities (Piper 1995; RGB 1991). Such implementation of the royal government should be identified as a kind of "ethnic cleansing" outside the kingdom, and thus over 100,000 people gave up remaining in Bhutan. As such, utmost 130,000 ethnic Nepalese fled the "happiest" kingdom in the late 1980s and early 1990s, contrary to the worldwide propagated image that Bhutan is "the world's happiest country."

\subsubsection{Refugee Camps in Eastern Nepal}

Legally, refugees should be treated under the Nepali laws applicable to foreigners because Nepal has not had any particular legislation regulating refugees, nor has the country signed the 1951 Refugee Convention and the 1967 Refugee Protocol (Mayilvagnan 2005). In front of the emergency and massive inflow of Nepali brothers, however, Nepal requested to the help of UNHCR by early 1992 (UNHCR 2016b). In cooperation with the government of Nepal, World Food Programme (WFP), IOM and other partner NGOS, UNHCR started its operation of utmost 7 refugee camps: Beldangi 1, 2, and Extension (52,756); Sanischare (21,320); Goldhap (9,632); Khudunabari (13,180); Timai (10,344) (IOM 2008).

Other than hosting over 100,000 Bhutanese refugees, Nepal has not willingly struggled for a solution of Bhutanese refugee problem. While the various governments holding power in 1990s adopted a similar policy on the Bhutanese refugee problem, Nepal could not but repeating its argument that Bhutan should take back its entire people from the refugee camps (Hutt 2005). At that time, Nepal severely suffered from the civil conflict, successive political failures, increasing population pressure and poor economy. Both governments of Nepal and Bhutan had a total of 15 bilateral talks on Bhutanese refugee problem with no agreed outcome (Nepali Times 2014). Bhutan has maintained its attitude that people in refugee camps had never Bhutanese citizens except that the kingdom recognized its full responsibility for 293 individuals in Khudunabari-camp as a result of the "join verification survey" in 2001 (Hutt 2005; Mayilvgnan 2005).

Under the current refugee regime, it is impossible for non-state actors including UNHCR solve the refugee problems because states have the ultimate responsibilities. India is the regional superpower in South Asia and also hosts a part of Bhutanese refugees, but the country has consistently maintained its neutral position that refugee problem is a bilateral issue between Bhutan and Nepal (Hutt 2005; Mayilvagnan 2005). Towards the unwillingness of Bhutan to take refugees, Nepal had failed in internationalizing the Bhutanese refugee problem (Hutt 2005) till the beginning of the third country resettlement.

\subsubsection{Third Country Resettlement}

Without any prospect that Bhutanese refugees would be granted citizenship in Bhutan or Nepal, the United States first announced its willingness to resettle up to 60,000 Bhutanese refugees in October 2006 (Human Rights Watch 2007). This offer was "part of efforts by the United Nations High Commissioner for Refugees (UNHCR) and the Core Working Group of countries trying to find a durable solution" (Moriarty 2007). In 2007, the third country resettlement program kicked off, in cooperation among UNHCR, IOM and 7 destination countries comprising the Core Working Group. To date, more than 100,000 Bhutanese refugees have resettled as follows.

\footnotetext{
${ }^{1}$ In 2001, Joint Verification Team (composed of 5 Nepali and 5 Bhutanese members) conducted this survey only in the Khudunabari camp. As a result of this survey, refugees were categorized as follows: (1)Bonafide Bhutanese: 293 individuals (74 families); (2)Bhutanese Deportee: 8595 individuals (2182 families); (3)Non-Bhutanese: 2948 individuals (817 families); (4) Bhutanese Criminals 347 individuals (85 families) (Hutt 2005; Mayilvagnan 2005).
} 
Table 1: Resettlement Statistics (as of February 29, 2016)

\begin{tabular}{|r|r|r|r|}
\hline Country & Submission & Acceptance & Total Departure \\
\hline Australia & 6,069 & 5,508 & 5,692 \\
\hline Canada & 7,327 & 6,850 & 6,667 \\
\hline Denmark & 961 & 887 & 874 \\
\hline Netherlands & 380 & 333 & 327 \\
\hline New Zealand & 1,444 & 1,064 & 1,002 \\
\hline Norway & 720 & 573 & 566 \\
\hline United Kingdom & 415 & 363 & 358 \\
\hline United States & 97,827 & 88,689 & 86,166 \\
\hline Total & 115,143 & 104,267 & 101,652 \\
\hline
\end{tabular}

Source: UNHCR (2016b)

At the beginning time, the number of applicants was less than the anticipation of UNHCR due to the lack of clear information about the resettlement offer or about the prospects for other durable solutions (voluntary repatriation and local integration), but the application number has gradually increased in accordance with the progress of the third country resettlement. According to a result of the profiling survey on camp-residing refugees UNHCR conducted in 2015, over half of survey respondents (54\%) expressed interest in resettlement to the third country, 30\% of respondents hoped to return to Bhutan and 14\% wished to remain in Nepal or India while 2\% undecided (UNHCR 2016a). As of March 2016, less than 18,000 refugees lived in the remaining two camps (Beldangi and Sanischare) and the population is estimated to be around 10,000 by the end of the year (Personal interview with a UNHCR officer at the UNHCR office in Damak, March 10, 2016).

\subsubsection{Refugee Communities in South Australia}

Australia is a leading country providing resettlement offers to Bhutanese refugees after the United States and Canada. In 2008, Australia announced to accept 5,000 Bhutanese refugees thorough its Special Humanitarian Programme (SHP) (DIAC 2014), but nearly 60,000 or more Bhutanese refugees have resettled, and their population and community are slowly but still expanding (Personal interview with the chairperson of Bhutanese refugee community in South Australia, August 8, 2016). In Australia, Bhutanese refugees are considered to spread all over the country, but a significant portion of them (probably over 50\%) reside in South Australia. ${ }^{2}$

The interviews with Bhutanese refugees found out that the biggest Bhutanese community is around Salisbury, particularly in South Australia. Salisbury is located in the near north of Adelaide (the capital of the State of South Australia), which accords with figures in Table2. The result of the 2011 Census uses the term "Bhutan-born South Australians," but almost all of them are identified as Bhutanese refugees from camps in Nepal because they reported that they migrated in 2008 or later (Multicultural SA 2014). Actually, most of the refugee informants of my research in South Australia work and reside in Salisbury.

2 According to the result of the National Census in 2011, South Australia had the largest number of Bhutan-born people (DIAC 2014). In Australia, National Census is conducted every five years and the latest one was in August 2016. This was the first census after the start of mainstream resettlement of Bhutanese refugees, and thus its result (that will be released in early 2017) will provide more detailed information on the demography and community information about Bhutanese refugees. 
Table 2: Areas of residence of Bhutan-born South Australians as of 2011

\begin{tabular}{|r|r|r|}
\hline Adelaide - Central and Hills & 32 & $4.5 \%$ \\
\hline Adelaide - North & 590 & $83.7 \%$ \\
\hline Adelaide - South & 20 & $2.8 \%$ \\
\hline Adelaide - West & 50 & $7.1 \%$ \\
\hline Regional South Australia & 10 & $1.4 \%$ \\
\hline No Usual Address (SA) & 3 & $0.4 \%$ \\
\hline Total & 705 & $100.0 \%$ \\
\hline
\end{tabular}

Source: Multicultural SA (2014)

Australia has consistently been a strong supporter of international efforts to address protracted situations of worldwide refugees and provided resettlement offers under the Australia's Humanitarian Program for refugees from such as Afghanistan, Burma and African states other than Bhutanese refugees (Personal interview with a local NGO worker in South Australia, August 9, 2016; DIAC 2009). It is also believed Australians generally have more respect for multiculturalism and open-mind to cultural differences because of the Australia's long-term experiences of migration, and particularly South Australia is where ethnic minorities including refugees are an integral part of a thriving, prosperous community. In fact, South Australians come from about 200 countries as well as 350,000 people (over 20\%) were born overseas (Multicultural SA n.d.). In South Australia, Bhutanese refugees organize the Bhutanese Australian Association of South Australia (BAASA), a community organization, and they have willingly tried to build good relations in and out of their community (Personal interview with Bhutanese refugees in South Australia, March 8, 2016).

It is not easy to create a situation desirable for all members of refugees and local residents in host community, according to an image, generated through media reports or pessimistic literature about disastrous refugee problems, that massive refugee inflow tends to cause a variety of socio-economic problems. Through my field research in South Australia, however, I witnessed a good atmosphere among Bhutanese refugees as well as between the refugees and the host community. Bhutanese community has made a positive contribution to host community bringing socio-economic benefits. Why has Bhutanese refugees not had antagonism with host community? Given that the case of Bhutanese refugees in South Australia is successful, what factors determine the successful integration? These are the questions for the discussion in the next section.

\subsection{Socio-Economic Impacts of Inflow of Refugees}

\subsubsection{Impacts on Local Economy}

This part focuses on the economic impacts Bhutanese refugees gave to host community in South Australia, but "what are the economic impacts of refugee resettlement" is a complicated question with the answer dependent on a wide range of issues and circumstances, as Stevenson (2005) said. The impacts and contributions appear to be different depending on whether analysis is conducted at a macro or microeconomic level (Stevenson 2005). Therefore, this study focuses specifically on the roles refugees can play in local economy.

As usual, "Regional Australia" can be defined broadly as areas outside of major cities (e.g. Sydney, Newcastle, Wollongong, Melbourne, Perth, Brisbane and the Gold Coast), and all areas in South Australia, except for the Adelaide city center, are included (DIRD 2015). About two thirds of Australia's export earnings are estimated to come from regional industries such as agriculture, tourism, retail, services and manufacturing (DIRD 2016), but many parts of regional Australia have been struggling economically, ecologically, and socially for their sustainability (Gray \& Lawrence 2001).

South Australian regions that most Bhutanese refugees resettled in are surely listed on the Regional Australia. For example, Salisbury (Northern Adelaide) is an industrial area with a geographical advantage in being located close to the capital and port city, Adelaide, and there are many employment opportunities in agriculture or manufacturing sector. Because of the Global Financial Crisis of 2007-2008, occurring at the same time as the Bhutanese refugee resettlement, many refugees unfortunately had a few difficulties to get access to employment, but now most of refugees, both men and women, work in a wide range of industries and give birth to benefits for local economy (Focus group interviews with Bhutanese refugees and local NGO workers, March 8-9, 2016). 
Compared to other regions in Australia, South Australia has advantages in the sectors of food and agriculture; advanced manufacturing; health and biomedical products; oil and gas, mining equipment; technology and services; tourism; and education (CoA 2014). In accordance with the expectations towards "mining boom" (DMITRE 2013), South Australian industries are anticipated to need more labor forces. How to ensure required labor forces, while the anticipations to economic growth as well as the concerns accompanied with aging populations are increasing, is a key agenda to maintain the development and social welfare. Refugees, including Bhutanese refugees, have potentials to make up the future labor needs, because they have contributed to local economy in South Australia.

\subsubsection{Social and Cultural Impacts}

In addition to the economic benefits, Bhutanese refugees have brought a positive contribution in the respect of diversity. South Australia has a lot of experiences of migrant inflows, as mentioned above, and not only South Australians come from about 200 countries, but also they have a variety of languages, religions and traditions (Multicultural SA n.d.).

Bhutanese refugees speak Nepalese as their main language spoken at home. As for the religions, around $80 \%$ of Bhutanese refugees follow Hiduism and less than $20 \%$ follow Tibetan Buddhism as well as they also have a few populations following other religions such as Christianity and Islam, in the same portion as Nepal. Religious and ethnic traditions are important part of their life, and they have maintained those traditions in the resettlement places (Personal interview with Bhutanese refugees in South Australia, March 8, 2016).

Like Bhutanese refugees, a variety of ethnic groups have their own communities respectively, but South Australia traditionally has atmosphere to promote cultural exchanges between different ethnic communities. Those communities have developed associations and shared their experiences or knowledges with each other, and the state government has supported those activities (Multicultural SA 2012). A significant portion of Bhutanese refugees, except for elderly people, can speak English well or very well, so they have no difficulty for interacting with other refugee or migrant communities. In fact, Bhutanese community has willingly cooperated with other communities such as Italian, German and Vietnamese communities (Personal interview with Bhutanese refugees in South Australia, March 8, 2016).

In South Australia, multiculturalism has been successfully practiced, which would be not particular nature in South Australia but all over the Australia. South Australia is truly where ethnic minorities including refugees are an integral part of a thriving, prosperous community. As such, social and cultural impacts are not large in the context of the resettlement of Bhutanese refugees in South Australia.

\section{DISCUSSIONS}

\subsection{Burden-Sharing Arguments}

The concept of refugees is emerged as a 'problem' in the international context (Haddad 2008). The identification of the joint-product model shows that there is no inevitability to the perception of refugees as a 'burden' (Betts 2003), and thus discourses in the field of refugee studies include the negative terms such as "crisis," "problem" and "burden," and frames refuge as a problem. Betts (2011) says that the contemporary refugee regime is mainly composed of two norms: "asylum" and "burden-sharing." "Asylum" is considered to relate to the provision of protection to refugees who reach the territory of that state, and "burden-sharing" is considered to be the provision of protection of refugees who are on the territory of another state through resettlement or financial contributions (Betts 2011).

As such, the recent discussions centralize in how "burden" and "responsibility" should be shared among international society. However, we need to notice that there are often widespread misconceptions about refugees. All refugees have their own lives the same as non-refugee people. Before leaving home, they had ordinal life with their family, friends and neighbors. Most refugees are more dependent on other social relationships and, in many cases, create sustainable livelihood opportunities for themselves, even if they do receive humanitarian assistance after their displacement (Betts, Bloom, Kaplan \& Omata 2014). As for Bhutanese refugees, in fact, they have no right to work or own land in Nepal under the existing rules and regulations, but they have worked in and around refugee camps as well as made refugee economies and societies (Personal interview with a UNHCR officer at the UNHCR office in Damak, March 10, 2016). In addition to contributing to local economy in camp-surrounding area in Eastern Nepal, Bhutanese refugees make various contributions to host community in resettlement place, South Australia, by making use of their experiences before resettlement.

Refugees are commonly dealt with as "burdens" on host community, but the case of Bhutanese refugees shows that we should rethink the widely spread assumptions. As a result of the exploration in Uganda, a research team of the Refugee Studies Centre, University of Oxford Refugees claims that refugees often make a positive contribution to the host state economy (Betts, Bloom, Kaplan and Omata 2014). Whether refugees are really "burden" or not depends on the individual case because various factors influence refugee resettlement, but the fact that refugees have potentially become contributions for host community should be noted. 


\subsection{Benefits for Host Communities}

In Australia, there are thousands of refugees living now. Refugees have great mental and physical strength, and these characteristics often influence them to have a great desire to succeed in building a new and better life, said Stevenson (2005). Contrary to the widespread myth that refugees become burdens on host community, refugees can potentially give birth to economic, social and cultural benefits for host community. Bhutanese refugee resettlement in South Australia is a good example.

According to the calculation by Australian government's Department of Human Services, refugees can earn a minimum of AUD 50,000 (USD 38,362) per year without doing anything other than being in the country (The New Observer 2016), but more importantly, refugees can potentially make invaluable contributions in business, academia, literature and every other field of life if given the opportunity (Steven 2005). Bhutanese refugees, both men and women, have actually had enormous success in South Australia, and an increasing number of them are buying long-term home by making use of a mortgage from HomeStart, a financial organization of Government of South Australia (HomeStart 2014ab; Marcus 2015).

Currently, demographic changes and particularly aging populations are big problems for Australia. South Australia already faces a risk of labor shortage, as it is already reported in the agricultural sector (The Adviser 2017), and especially in the sectors of engineering and science technology, health, childcare and education, skilled labor shortages or recruitment difficulties are emerging (DE 2016). Among refugee community, the majority of younger generations are highly motivated to work and study in Australia, and they are trying to contribute to host community (Personal interview with Bhutanese refugees in South Australia, March 8, 2016). Refugee labors would have potentials to make up the future labor needs. Needless to say, Australian government has not spent a few costs for Bhutanese refugee resettlement. However, long-term benefits refugees bring should outweigh the short-term costs.

\section{CONCLUSION}

In this paper, I argue that refugees are never burdens on host community, but several conditions should be required to back up this argument. Firstly, supports and experiences before resettlement should be important. It may be meaningless to compare the refugee camps in Nepal with other refugee camps in other countries, but security situations in Bhutanese refugee camps have been much better than other refugee camps in other poor developing countries, and those relatively good situations enabled UNHCR, IOM and other partner organizations to easily conduct aid activities (Personal interview with a UNHCR officer and local NGO doctor in Damak, March 10-11, 2016). Although there were lots of limitations, aid agencies have provided a variety of supports, such as food and housing support; health and medical services; child and youth education; or adult education and vocational training (CoA 2007; IOM 2008), which contribute to the higher literacy rates and better health of Bhutanese refugees (Personal interview with a UNHCR officer and local NGO doctor in Damak, March 10-11, 2016). Relatively better conditions and supports in refugee camps would make Bhutanese refugees smoothly reconstruct their livelihoods in South Australia.

Secondly, supports after resettlement should not be forgotten. Currently, Australia's immigration program is divided into two systems: one is the Migration program for skilled and family migrants, and the other is the Humanitarian Program for refugees and others in refugee-like situations, and moreover the latter Humanitarian Program is divided into onshore program for those who are already in Australia and offshore one for those who are not (Buckmaster 2012). All offshore refugees, including Bhutanese refugees, can enjoy the intensive settlement supports named as the Humanitarian Settlement Services (HSS). HSS is a need-based system, but it enables to refugees to be granted governmental supports for up to 12 months (DSS 2016; RCA 2016), whose duration is said to be longer than other country's similar services.

Thirdly and the most importantly, the nature of resettlement area should determine the consequences of refugee resettlement. In this respect, South Australia has the best conditions for refugees to resettle in. In South Australia, there are lots of employment opportunities, and the region need labor forces that refugees can potentially provide, which cause less economic matters. Also, South Australia has historically lots of experiences to accept refugees from Vietnam, Afghanistan, Burma (Myanmar), and so on. Related to the social or cultural impacts, plenty of experiences of the region have had a positive effect on the smooth resettlement of Bhutanese refugees, and few negative impacts on host community.

Are refugees really burdens on host communities? The answer depends on the individual case, needless to say. A variety of factors influence refugee resettlement and it is difficult to identify the specific contributions of one factor from those of others. Refugees tend to be labelled as "burdens" in media articles or refugee literature, but we should rethink the widely spread assumptions. As I showed through the successful resettlement case of Bhutanese refugees, refugees have potentials to become "assets" giving birth to benefits for host community. Among the gloomy atmosphere related to the refugee crisis, scholars and practitioners start advocating the necessity of reforming the international refugee regime (Koser 2015; Sieqfried 2016). Before discussing the reform, we should pose a question to the firmly rooted notion that "refugees are burdens," and this study concludes that there are plenty of potentials of refugees to become assets for host community. 


\section{ACKNOWLEDGEMENT}

This work was supported by the Graduate School of Frontier Sciences of the University of Tokyo. I am also deeply thankful to all of my informants though their names cannot be disclosed. Their information has helped me complete this paper.

\section{REFERENCES}

[1] AHURA Bhutan (Association of Human Rights Activists, Bhutan). (1994). Bhutanese Refugees: Victims of Arbitrary Deprivation of Right to Nationality and Political Repression. A Report by AHURA Bhutan, August 1.

[2] Betts, A. (2003). Public Goods Theory and the Provision of Refugee Protection: The role of the Joint-Product Model in Burden-Sharing Theory. Journal of Refugee Studies, 16(3), 274-296. https://doi.10.1093/jrs/16.3.274

[3] Betts, A. (2009). Forced Migration and Global Politics. Wiley-Blackwell.

[4] Betts, A. (2011). International Cooperation in the Refugee Regime. In Betts, Alexander \& Loescher, Gil. (Eds.), Refugees in International Relations. Oxford University Press.

[5] Betts, A., Bloom, L., Kaplan, J. \& Omata, N. (2014). Refugee Economies: Rethinking Popular Assumptions. Retrieved from https://www.rsc.ox.ac.uk/files/publications/other/refugee-economies-2014.pdf (accessed March 22, 2017).

[6] Betts, A. \& Loescher, G. (2011). Refugees in International Relations. In Betts, A. \& Loescher, G. (Eds.), Refugees in International Relations. Oxford University Press.

[7] Betts, A., Loescher, G. \& Milner, J. (2012). UNHCR: The politics and Practice of Refugee Protection, Second edition. Routledge.

[8] Buckmaster, L. (2012). Australian Government assistance to refugees: fact versus fiction. Background Note for the Department of Parliamentary Services, Parliament of Australia, September 28. Retrieved from http://www.aph.gov.au/About_Parliament/Parliamentary_Departments/Parliamentary_Library/pubs/BN/20122013/AustGovAssistRefugees\#_Toc336609240 (accessed April 15, 2017).

[9] CoA (Commonwealth of Australia). (2007). Bhutanese Community Profile. Retrieved from https://www.dss.gov.au/sites/default/files/documents/11_2013/community-profile-bhutan.pdf (accessed April 15, 2017).

[10] CoA. (2014). Growing Opportunities: South Australian and Victorian Comparative Advantages. Report of the Panels for the Reviews of the South Australian and Victorian Economies. Retrieved from https://industry.gov.au/aboutus/corporatepublications/reviewofsouthaustralianandvictorianeconomies/documents /growingopportunities-southaustraliaandvictoria.pdf (accessedApril 15, 2017).

[11]DE (Department of Employment). (2016). Skill Shortage List South Australia. Retrieved from https://docs.employment.gov.au/system/files/doc/other/skillshortagelistsa_6.pdf (accessed April 15, 2017).

[12] DIAC (Department of Immigration and Citizenship). (2007). Bhutanese Community Profile. Commonwealth of Australia. Retrieved from https://www.dss.gov.au/sites/default/files/documents/11_2013/community-profilebhutan.pdf (accessed April 15, 2017).

[13]DIAC. (2009). Refugee and Humanitarian Issues: Australia's Response. Retrieved from http://library.bsl.org.au/jspui/bitstream/1/1614/1/refugee-humanitarian-issues-june09.pdf (accessed April 15, 2017).

[14] DIAC. (2014). Special Humanitarian Programme (SHP): A handout of Australian High Commission in New Delhi. Retrieved from http://bhutanesesa.org.au/uploads/2014/04/SPH-Handout.pdf (accessed April 15, 2017).

[15]DIRD (Department of Infrastructure and Regional Development). (2015). State of Regional Australia 2015: Progress in Australian Regions. Retrieved from http://regional.gov.au/regional/publications/sora/files/State-ofRegional-Australia-2015.pdf (accessed April 15, 2017).

[16]DIRD. (2016). Regional: A website of the Department of Infrastructure and Regional Development, Australian Government. Last Updated on August 25, 2016. Retrieved from http://regional.gov.au/regional/ (accessed April 15, 2017).

[17]DMITRE (Department for Manufacturing, Innovation, Trade, Resources and Energy). (2013). Realising the benefits of the mining boom for all South Australians. Retrieved from http://www.resa.org.au/media/3238/realising-the-resources-boom-dec-2013.pdf (accessed April 15, 2017).

[18]DSS (Department of Social Services). (2016). Humanitarian Settlement Services (HSS), Settlement and Multicultural Affairs. Last updated on September 9, 2016. Retrieved from https://www.dss.gov.au/ourresponsibilities/settlement-and-multicultural-affairs/programs-policy/settlement-services/humanitariansettlement-services-hss (accessed April 15, 2017).

[19] Gray, I. \& Lawrence, G. (2001). A future for regional Australia: escaping global misfortune. Cambridge University Press.

[20] Haddad, E. (2008). The Refugee in International Society Between Sovereigns. Cambridge University Press. 
[21] HomeStart. (2014a). Bhutanese refugees building communities in SA. Media release of HomeStart, May 27. Retrieved from https://www.homestart.com.au/getmedia/89544d83-4712-45e8-8e18-38bf86194fd3/Bhutaneserefugees-building-communities.pdf (accessed April 15, 2017).

[22] HomeStart. (2014b). Bhutanese battlers find home away from home in Adelaide's north. Media release of HomeStart, June 17. Retrieved from https://www.homestart.com.au/getmedia/0636c457-736b-4eed-b458aa2a9a6c7295/Bhutanese-battlers-find-home.pdf (accessed April 15, 2017).

[23] Human Rights Watch. (2007). Last Hope: The Need for Durable Solutions for Bhutanese refugees in Nepal and India. Human Rights Watch Reports, 19(7c), Retrieved from https://www.hrw.org/sites/default/files/reports/bhutan0507webwcover.pdf (accessed April 15, 2017).

[24]Hutt, M. (1996). Ethnic Nationalism, Refugees and Bhutan. Journal of Refugee Studies, 9 (4), $397-420$. https://doi.org/10.1093/jrs/9.4.397

[25]Hutt, M. (1997). Being Nepali without Nepal: reflections on a South Asian diaspora. In: Gellner, D., PfaffCzarnecka, J., and Whelpton, J. (Eds.), Nationalism and Ethnicity in a Hindu Kingdom: The Politics of Culture in Contemporary Nepal. Harwood Academic Publishers (Amsterdam), 101-144.

[26]Hutt, M. (2005). The Bhutanese Refugees: Between Verification, Repatriation and Royal Realpolitik. Peace and Democracy in South Asia, 1(1), 44-56.

[27] IOM (International Organization for Migration). (2008). Cultural profile: The Bhutanese refugees in Nepal; A tool for settlement workers and sponsors. Retrieved from https://www.google.ae/url?sa=t\&rct=j\&q=\&esrc=s\&source=web\&cd=1\&cad=rja\&uact=8\&ved=0ahUKEwjcu Me91J7SAhXKKMAKHZkrCJwQFggaMAA\&url=http\%3A\%2F\%2Fwww.peianc.com\%2Fsitefiles\%2FFile\%2 Fresources\%2Fcultural_profiles\%2FBhutanese-Refugees-in-

Nepal.pdf\&usg=AFQjCNElhZBKeU6deBXnD4Mbo0smdBoGzQ (accessed April 15, 2017).

[28]IOM. (2015). Resettlement of Refugees from Bhutan Tops 100,000. IOM, November 20. Retrieved from http://www.iom.int/news/resettlement-refugees-bhutan-tops-100000 (accessed April 15, 2017).

[29] Karlsen, E. (2016). Refugee resettlement to Australia: what are the facts? Parliament of Australia, September 7. Retrieved

from http://www.aph.gov.au/About_Parliament/Parliamentary_Departments/Parliamentary_Library/pubs/rp/rp1617/R efugeeResettlement\#_Toc461022105 (accessed April 15, 2017).

[30] Koser, K. (2015). Time to reform the international refugee regime. Oxford University Press's blog. Retrieved from http://blog.oup.com/2015/09/international-refugee-regime-reform/ (accessed April 15, 2017).

[31] Marcus, C. (2015). Number of Bhutanese refugees buying homes in Adelaide continue to grow. ABS, June 16. Retrieved from http://www.abc.net.au/news/2015-06-16/number-of-bhutanese-refugees-buying-homescontinues-to-grow/6547318 (accessed April 15, 2017).

[32] Mayilvaganan, M. (2005). Bhutanese Refugees in Nepal: Problems and Prospects. Nepali Journal of Contemporary Studies, 5(2), 1-19.

[33] MoHA (Ministry of Home Affairs of Bhutan). (1958). The Nationality Law of Bhutan, 1958. Retrieved from http://www.nab.gov.bt/assets/uploads/docs/acts/2014/National_Law_of_Bhutan_1958Eng.pdf (accessed April 15, 2017).

[34] MoHA. (1980). Marriage Act of Bhutan, 1980. Retrieved from http://oag.gov.bt/wpcontent/uploads/2010/05/Marriage-Act-of-Bhutan-1980English-version.pdf (accessed April 15, 2017).

[35] MoHA. (1985). The Bhutan Citizen Act, 1985. Retrieved from http://www.nab.gov.bt/assets/uploads/docs/acts/2014/Bhutan_Citizen_Act_1985Eng.pdf (accessed April 15, 2017).

[36] MoHA. (1993). Census Hand $\quad$ Book, $1993 . \quad$ Retrieved from http://www.nab.gov.bt/assets/uploads/docs/acts/2014/Census_Hand_Book1993Eng.pdf (accessed April 15, 2017).

[37] Moriarty, J. (2007). Ambassador James F. Moriarty’s Remarks to Bhutanese Refugee on the U.S. Resettlement Program, May 25. Retrieved from http://nepal.usembassy.gov/sp-05-25-2007.html (accessed April 15, 2017).

[38] Multicultural SA. (2012). Coordination of Settlement Services: Ensuring Humanitarian Migrants in South Australia Get a Fair Go. A report of Multicultural SA, Government of South Australia. Retrieved from http://www.multicultural.sa.gov.au/_data/assets/pdf_file/0010/2206/coordination-of-settlement-services2012.pdf (accessed April 15, 2017).

[39] Multicultural SA. (2014). Bhutan: A profile of Bhutan-born South Australians. Retrieved from http://www.multicultural.sa.gov.au/_data/assets/pdf_file/0007/22021/Bhutan-Dec-2014.pdf (accessed April 15, 2017).

[40] Multicultural SA. (n.d.) South Australia's diversity, Statistics in the website of Government of South Australia. Retrieved from http://www.multicultural.sa.gov.au/communities-in-sa/statistics (accessed April 15, 2017).

[41] Nepali Times. (2014). An (inter)national disgrace: SAARC fails to confront the Bhutan refugee issue. Nepali Times. Retrieved from http://nepalitimes.com/regular-columns/The-gadfly/saarc-fails-to-confront-bhutaneserefugees-issue,401 (accessed April 15, 2017). 
[42] Newman, E. (2003). Refugees, international security, and human vulnerability: Introduction and survey. In Newman, E. \& Van-Selm, J. (Eds.), Refugees and Forced Displacement: International Security, Human Vulnerability, and the State. United Nations University Press.

[43] Piper, T. (1995). The Exodus of Ethnic Nepalis from southern Bhutan. WRITENET, April 1. Retrieved from http://www.refworld.org/docid/3ae6a6c08.html (accessed April 15, 2017).

[44] Preiss, D. (2016). As Bhutanese refugee camps in Nepal wind down, resettlement program is considered a success. Public Radio International, December 28. Retrieved from https://www.pri.org/stories/2016-1228/bhutanese-refugee-camps-nepal-wind-down-resettlement-program-considered-success (accessed April 15, 2017).

[45] RCA (Refugee Council of Australia). (2016). Humanitarian Settlement Services (HSS), July 4. Retrieved from http://www.refugeecouncil.org.au/getfacts/settlement/hss/ (accessed April 15, 2017).

[46]RGB (Royal Government of Bhutan). (1991). Anti-national Activities in Southern Bhutan: a Terrorist Movement. Thimphu: Department of Information.

[47] Sieqfried, K. (2016). Time to reform the way we protect refugees? IRIN, May 9. Retrieved from http://www.irinnews.org/analysis/2016/05/09/time-reform-way-we-protect-refugees (accessed April 15, 2017).

[48] Stevenson, R. (2005). Refugees and Economic Contributions. Background Paper for the Hopes Fulfilled or Dreams Shattered? From resettlement to settlement Conference November 23-28, 2005. Retrieved from https://www.crr.unsw.edu.au/media/CRRFile/Refugees_and_Economic_Contributions.pdf (accessed April 15, 2017).

[49] Suhrke, A. (1998). Burden-Sharing During Refugee Emergencies: The Logic of Collective Action Versus National Action. Journal of Refugee Studies, 11(4), 396-415. https://doi.org/10.1093/jrs/11.4.396

[50] The Adviser. (2017). Worker shortage crippling growth of South Australia's horticulture industry. The Adviser, January 4. Retrieved from http://www.adelaidenow.com.au/news/south-australia/worker-shortage-cripplinggrowth-of-south-australias-horticulture-industry/news-story/1cb081befd6285db1ff79e58f9fd2f30 (accessed April 15, 2017).

[51] The New Observer. (2016). Australia: "Refugees” Earn \$50,000 pa. The New Observer, April 3. Retrieved from http://newobserveronline.com/australia-refugees-earn-50000-pa/ (accessed April 15, 2017).

[52] UNHCR (Office of the United Nations High Commissioner for Refugees). (2015). Resettlement of Bhutanese refugees $\quad$ surpasses mark. $\quad 100,000 \quad$ Retrieved from http://www.unhcr.org/news/latest/2015/11/564dded46/resettlement-bhutanese-refugees-surpasses-100000mark.html?query=Bhutanese\%20refugee (accessed April 15, 2017).

[53]UNHCR. (2016a). Final Report of the Profiling Exercise of Refugees from Bhutan. A report of UNHCR SubOffice Damak, Jhapa, Nepal, February 9. Unpublished manuscript.

[54] UNHCR . (2016b). 1 refugee without hope is too many. A briefing note of UNHCR Sub-Office Damak, Jhapa, Nepal. Unpublished manuscript. 